\title{
Design, Synthesis and Calcium Channel Blocking Activity of Diltiazem- Verapamil Hybrid Molecules
}

\section{Ahmed S Mehanna ${ }^{1 *}$, Timothy J Maher ${ }^{1}$ and Pintapa P Grongsaard ${ }^{2}$}

${ }^{1}$ Department of Pharmaceutical Sciences, School of Pharmacy-Boston, MCPHS University, 179 Longwood Avenue, Boston MA 02115, USA

${ }^{2}$ Processing Chemist, Department of Process Chemistry, Merck \& Co. Inc., 126 East Lincoln Avenue, Rahway, New Jersey 07065, USA

\begin{abstract}
The current manuscript describes the design, synthesis, and in vitro testing of four thioacetanilides with diltiazemverapamil hybrid structural features as potential calcium channel blockers. The current hybrid strategy of drug design aimed to generate compounds that could span, with a single compound, the trans-membrane locales where the two drugs bind, with the ultimate goal of increasing the blocking activity. The latter, was assessed by measuring the inhibitory effects, expressed as $\mathrm{IC}_{50}$, on calcium-induced contractions of potassium depolarized isolated rat aorta strips. The assessment of the binding locales was determined by incubating the test compound with aortic strips for two different periods, 10-minutes and 2-hours, before adding the contractile calcium ions to the assay medium. Diltiazem $\mathrm{IC}_{50}$ values were 0.26 and $0.14 \mu \mathrm{M}$, after 10-minutes and 2-hours, respectively, reflecting less than two fold increase in activity and confirming previous reports that its locale of binding in mostly on the exterior side of the membrane. On the other hand, verapamil $\mathrm{IC}_{50}$ values were 0.47 and $0.14 \mu \mathrm{M}$ after 10-minutes and 2-hour incubation respectively, reflecting approximately a 3-4 fold increase in activity and confirming previous reports that it binds mainly to the interior domains of the membrane. The four designed hybrid compounds showed, after 10-minute incubation, an $\mathrm{IC}_{50}$ value range of 3.7-12.0 $\mu \mathrm{M}$, and after 2-hour incubation an $\mathrm{IC}_{50}$ range of $0.78-2.12 \mu \mathrm{M}$, reflecting approximately a 5 -fold increase in activity suggesting more similarity to the verapamil binding profile. The data indicate that the designed compounds are with moderate activities, but generally less active as calcium channel blockers than either of the two parent drugs.
\end{abstract}

Keywords: Calcium channel blockers; Diltiazem; Verapamil; Thioacetanilides; Cardiovascular agents; Hybrid molecules

\section{Introduction}

Calcium channel blockers (CCB) have been a widely used class of drugs in the treatment of various cardiovascular disorders such as hypertension, angina and arrhythmia [1]. In the past few years, the clinical value of CCB has expanded by finding their way into the treatment of several other disease conditions; including: glaucoma [2], psychiatric disorders [3], Parkinson's disease [4,5], wound healing [6,7], epilepsy [8], and in preventing some of the complication of diabetes $[9,10]$.

\section{Rationale of Design of the Current Compounds}

The design of the current hybrid molecules was prompted by earlier reports that diltiazem binds to calcium channels at a transmembrane region near the extracellular surface, while verapamil binds to a region located toward the intracellular side of the membrane [11-15]. In search of newer CCB with dual affinity to both diltiazem and verapamil binding domains, we designed four hybrid molecules combining important pharmacophores of both drugs, with the ultimate goal to generate compounds with higher activity than the parent drugs. Chemically, the hybrid molecules are o-thioacetanilide derivatives (Figure 1), combining the o-thio-anilino-pharmacophore of diltazem and the homoveratrylamine pharmacophore of verapamil. The lipophilic group on the sulfur atom of the hybrid structures was either p-methoxy benzyl (compounds 4\&5), or p-methoxy phenyl (compounds 9\&10). The homoveratrylamine moiety was either secondary (compounds 4\&9), or tertiary (compounds 5\&10).

\section{Synthetic Scheme}

The compounds were synthesized according to a novel synthetic scheme as outlined in Figure 2. Intermediate 1 required the reaction of 2-chloronitrobenzene with 4-methoxybenzylmercaptan in dimethylformamide. Treatment of 1 with stannous chloride in acidic medium gave the reduced intermediate 2 . Reaction of the latter with chloroacetyl chloride in acetic acid gave intermediate 3. Target compounds $4 \& 5$ were obtained by reaction of 3 with homoveratrylamine and its N-methyl derivative, respectively. Similarly, by using 4-methoxythiophenol as a starting reagent instead of the

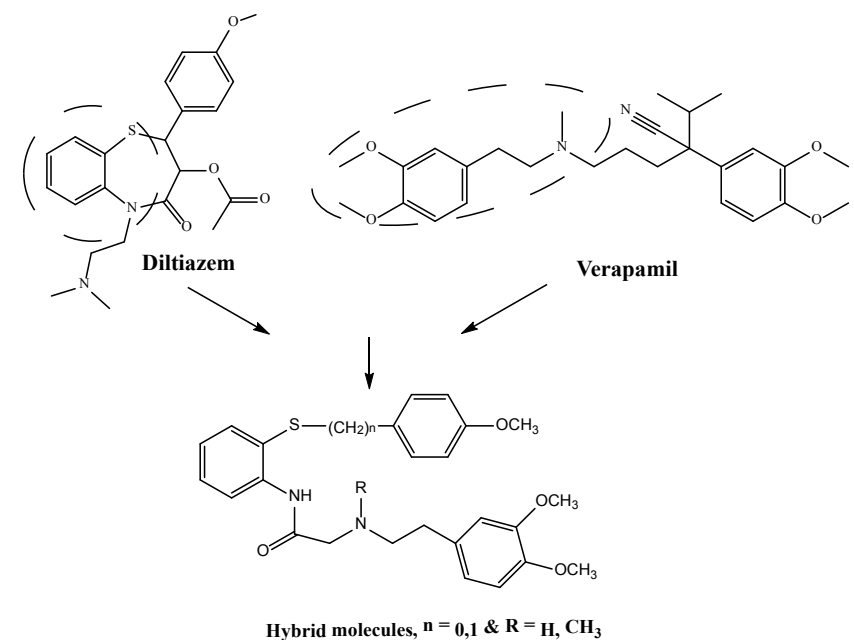

Figure 1: Structures of diltiazem, verapamil and proposed hybrid molecules.

*Corresponding author: Ahmed Mehanna, Professor of Medicinal Chemistry Department of Pharmaceutical Sciences, School of Pharmacy-Boston, MCPHS University, 179 Longwood Avenue, Boston MA 02115, USA, Tel: +617-732-2955; Fax: +617-732-2228; E-mail: ahmed.mehanna@mcphs.edu

Received August 20, 2014; Accepted September 25, 2014; Published September 27,2014

Citation: Mehanna AS, Maher TJ, Grongsaard PP (2014) Design, Synthesis and Calcium Channel Blocking Activity of Diltiazem-Verapamil Hybrid Molecules. Med chem 4: 704-703. doi:10.4172/2161-0444.1000216

Copyright: (c) 2014 Mehanna AS, et al. This is an open-access article distributed under the terms of the Creative Commons Attribution License, which permits unrestricted use, distribution, and reproduction in any medium, provided the original author and source are credited. 


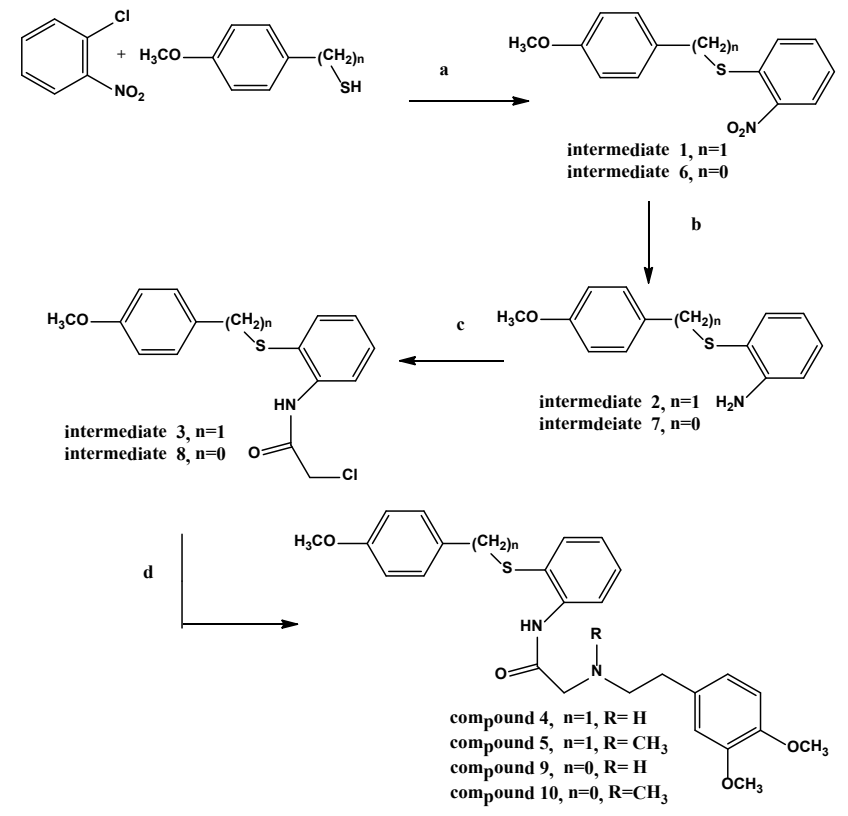

Figure 2: Synthetic scheme to prepare the hybrid compounds.

a.Sodiumethoxide/DMF/95- $100{ }^{\circ} \mathrm{C}$ or Sodium carbonate/95\% ethanol/85 ${ }^{\circ} \mathrm{C}$ for intermediates 1 and 6 , respectively.

b. $\mathrm{SnCl} / \mathrm{CH}_{3} \mathrm{COOH} / \mathrm{HCl} / / 950^{\circ} \mathrm{C}$

c. Chloracetylchloride/ $\mathrm{CH}_{3} \mathrm{COOH}$

d. Homoveratrylamine for $\mathbf{4 \& 9}$, or $\mathrm{N}$-methylhomoveratrylamine for 5 \&10/ benzene/reflux

4-methoxybenzylmercaptan the corresponding intermediates 6,7 \& 8 were obtained, and ultimately compounds $9 \& 10$. Final products were isolated as hydrochloride salts and in some cases as free bases. Percentage yields and compound characterizations, elemental analyses, melting points, IR and NMR data, are reported under the experimental section.

\section{Evaluation of Calcium Channel Blocking Activities}

The assay method employed to evaluate the calcium channel blocking activities for the current series of hybrid compounds, as well as that of the diltiazem and verapamil, was adapted from a previously established protocol [16]. The assay requires incubation of the compound to be evaluated with the isolated rat aortic strips in potassium-rich Krebs medium for 10-minutes, before adding calcium chloride to induce the aortic smooth muscle contraction. The compounds were dissolved with the help of ethanol, as detailed under the experimental section, that was added to the control runs to eliminate any solvent effect on the aortic strips contractions. We have previously applied the same protocol to evaluate the calcium channel blocking activities of a series of diltiazem-like compounds [17]. The same protocol was also applied in the current research for assessing the activity of the newly designed compounds and the two parent drugs but after incubation for 2-hours, before adding the contractile calcium ions. It must be pointed out that the $\mathrm{IC}_{50}$ values obtained for diltiazem and verapamil after 10 -minute incubation (Table 1), are identical to the values obtained for the two drugs determined by another technique involving microfluorometryanalytical tool as cited in Table 1.

\section{Experimental}

\section{Syntheses}

Melting points were determined in open glass capillaries with a Mel-Temp apparatus and are uncorrected. IR spectra were taken as $\mathrm{KBr}$ pellets with a Nicolet Impact $410 \mathrm{FT}$-IR spectrophotometer (Nicolet Instrument Corporation, Madison, WI). ${ }^{1} \mathrm{H}$ NMR spectra were obtained on a Varian T-60 NMR spectrometer (Varian Associates, Inc., Palo Alto, CA) or a Bruker AC 300 NMR spectrometer (Bruker Instruments, Inc., Billerica, MA) with tetramethylsilane (TMS) as an internal standard; the values of chemical shift $(\delta)$ are given in parts per million (ppm) and coupling constants $(J)$ in hertz $(\mathrm{Hz})$. Elemental analyses were performed new compounds by Desert Analytics, Tucson, $\mathrm{AZ}$, and are within $\pm 0.4 \%$ of the theoretical values. TLC on silica gel plate (Whatman, PE SIL G/UV) was employed to monitor progress of the reaction. Extracts were dried over magnesium sulfate or sodium sulfate, and solvents were removed under reduced pressure. Yields refer to the purified products and were not optimized.

\section{2-(4-Methoxybenzylthio)-1-nitrobenzene (1)}

Sodium spheres ( $3.4 \mathrm{~g}$ dried of mineral spirits) were dissolved in 70 $\mathrm{mL}$ absolute ethanol. The excess ethanol was distilled off under reduced pressure prior to the addition of 4-methoxy- $\alpha$-toluenethiol $(24.1 \mathrm{~g}$, $0.16 \mathrm{~mol}$ in $80 \mathrm{~mL} \mathrm{DMF}$ ). The mixture was stirred for 30 minutes. To this mixture, 1-chloro-2-nitrobenzene $(22.2 \mathrm{~g}, 0.14 \mathrm{~mol}$ in $60 \mathrm{~mL}$ DMF) was added; at this point an increase in temperature to $50^{\circ} \mathrm{C}$ was observed. The resulting yellow suspension was heated on a water bath $\left(70^{\circ}-80^{\circ} \mathrm{C}\right.$ for 3 -hours then at $90^{\circ}-100^{\circ} \mathrm{C}$ for 30 -minutes), subsequently the mixture was allowed to cool to room temperature. The precipitated sodium chloride was filtered off and the filtrate was chilled at $-20^{\circ} \mathrm{C}$ overnight. The yellow crystalline material was collected by filtration to yield $30.4 \mathrm{~g}(88 \%)$ of 1 . The crystals were subsequently recrystallized from ethanol to yield yellow needles with a melting point of $108^{\circ}-109^{\circ} \mathrm{C}$ and the following spectral properties: IR (KBr): 3080, 2950, 2920, 1505, $1330(\mathrm{O}=\mathrm{N}=\mathrm{O}), 1248,1029(\mathrm{C}-\mathrm{O}-\mathrm{C}), 820(\mathrm{C}-\mathrm{N}), 737 \mathrm{~cm}^{-1}{ }^{1} \mathrm{H}$ NMR $(60$ $\left.\mathrm{MHz}, \mathrm{CDCl}_{3}\right): 3.77\left(\mathrm{~s}, 3 \mathrm{H},-\mathrm{OCH}_{3}\right), 4.1\left(\mathrm{~s}, 2 \mathrm{H}, \mathrm{S}-\mathrm{CH}_{2}\right), 6.8(\mathrm{~d}, J=11,2 \mathrm{H}$, $\left.\mathrm{H}^{3}, \mathrm{H}^{5}\right), 7.3\left(\mathrm{~d}, J=11,2 \mathrm{H}, \mathrm{H}^{2}, \mathrm{H}^{6}\right), 7.0-7.5(\mathrm{~m}, 3 \mathrm{H}), 8.1\left(\mathrm{~d}, J=8,1 \mathrm{H}, \mathrm{H}^{6}\right)$. $\mathrm{C}_{14} \mathrm{H}_{13} \mathrm{NO}_{3}$ S. Calculated: C; 61.07, H; 4.76, N; 5.09, Found : C; 61.28, H; $4.79, \mathrm{~N} ; 5.19$.

\section{2-(4-Methoxybenzylthio) aniline (2) $[18,19]$}

Stannous chloride dihydrate ( $167.9 \mathrm{~g}, 0.74 \mathrm{~mol}$ ) was dissolved in 225 $\mathrm{mL}$ of concentrated hydrochloric acid in a 3-liter flask and the mixture was stirred to obtain a homogeneous suspension. To this suspension, compound 1 ( $34.1 \mathrm{~g}, 0.12 \mathrm{~mol}$ ) suspended in $335 \mathrm{~mL}$ glacial acetic acid was added. A mild exothermic reaction to $49^{\circ} \mathrm{C}$ was observed. The reaction mixture was heated at $80^{\circ}-100^{\circ} \mathrm{C}$ for 30 -minutes until the mixture became colorless. The mixture was chilled in an ice bath with simultaneous slow addition of $2 \mathrm{~L}$ sodium hydroxide solution $(6 \mathrm{M})$ to render the mixture strongly alkaline. The gray flaky solid formed was filtered through a sintered-glass funnel, washed with $400 \mathrm{~mL}$ cold water and left to air dry. The crude product $(29.7 \mathrm{~g})$ was taken up in $120 \mathrm{~mL}$ of t-butyl methyl ether. The un-dissolved material was filtered and to

\begin{tabular}{|r|c|c|c|c|c|c|}
\hline \multicolumn{4}{|c|}{} & \multicolumn{2}{c|}{$\mathbf{1 0 - \text { minute incubation }}$} & \multicolumn{2}{|c|}{ 2-hour incubation } \\
\hline Comp. & $\mathrm{R}$ & $\mathrm{n}$ & $\mathbf{I C 5 0}(\boldsymbol{\mu M})$ & SD & IC $_{\mathbf{5 0}}(\boldsymbol{\mu} \mathbf{M})$ & SD \\
\hline 4 & $\mathrm{H}$ & 1 & 6.79 & 0.12 & 1.58 & 0.54 \\
\hline 5 & $\mathrm{CH} 3$ & 1 & 3.72 & 0.26 & 0.78 & 0.07 \\
\hline 9 & $\mathrm{H}$ & 0 & 8.85 & 1.67 & 2.59 & 0.51 \\
\hline 10 & $\mathrm{CH} 3$ & 0 & 12.01 & 0.13 & 2.12 & 0.16 \\
\hline & Diltiazem & & $0.26^{*}$ & 0.06 & 0.14 & 0.02 \\
\hline & Verapamil & $0.45^{\star *}$ & 0.12 & 0.12 & 0.11 \\
\hline
\end{tabular}

Experiments were repeated for four times for each compound at each incubation time tested.

${ }^{*}$ Reported $0.30 \mu \mathrm{M}[20],{ }^{* *}$ Reported $0.47 \mu \mathrm{M}[20]$.

Table 1: $\mathrm{IC}_{50}(\mu \mathrm{M})$ values of hybrid compounds, diltiazem and verapamil after 10-minute and 2-hour incubation times. 
the filtrate was added an equivalent volume of hexane until the mixture became cloudy. Seeded and left overnight at $4^{\circ} \mathrm{C}$, the mixture yielded an ivory crystalline of 2 (21.3 g, 70\%-yield) that was then collected and washed with hexane. The ivory crystal, which turned slightly darker upon exposure to air, had a melting point range of $67^{\circ}-68.2^{\circ} \mathrm{C}$ and the following spectral properties: IR $(\mathrm{KBr}): 3455,3354(\mathrm{~N}-\mathrm{H}), 1600,1510$, $1476(\mathrm{C}=\mathrm{C}), 1251,1032(\mathrm{C}-\mathrm{O}-\mathrm{C}), 747 \mathrm{~cm}^{-1}{ }^{1} \mathrm{H}$ NMR $\left(60 \mathrm{MHz}, \mathrm{CDCl}_{3}\right)$ : $3.73\left(\mathrm{~s}, 3 \mathrm{H},-\mathrm{OCH}_{3}\right), 3.83\left(\mathrm{~s}, 2 \mathrm{H}, \mathrm{S}-\mathrm{CH}_{2}\right), 4.2\left(\mathrm{br}, 2 \mathrm{H}, \mathrm{NH}_{2}\right), 6.4-7.2(\mathrm{~m}$, $8 \mathrm{H}) . \mathrm{C}_{14} \mathrm{H}_{15} \mathrm{NOS}$. Calculated: C; 68.54, H; 6.16, N; 5.71, Found: C; 68.69, $\mathrm{H} ; 5.89, \mathrm{~N} ; 5.85$.

\section{2'-(4-methoxybenzylthio)-2-chloroacetanilide (3)}

Chloroacetyl chloride $(12.2 \mathrm{~g}, 0.11 \mathrm{~mol})$ was added drop-wise to a stirred solution of $2(22.1 \mathrm{~g}, 0.1 \mathrm{~mol})$ in $300 \mathrm{~mL}$ glacial acetic acid. A milky white precipitate appeared immediately. After 1 hour stirring, the reaction was quenched with sodium acetate solution (49 $\mathrm{g}$ in 150 $\mathrm{mL}$ water) and additional $150 \mathrm{~mL}$ of water was introduced, resulting in cloudy suspension and the separation of a yellow oil. The mixture was extracted with two portions of $200 \mathrm{~mL}$ chloroform. The organic layer was combined and successively extracted with two portions of $100 \mathrm{~mL}$ hydrochloric acid $(6 \mathrm{M})$, three portions of $150 \mathrm{~mL}$ sodium hydroxide $(6 \mathrm{M})$, and one portion of $50 \mathrm{~mL}$ water. The organic component was dried with magnesium sulfate and the solvent was removed under reduced pressure. The thick yellow oil residue was left at $40^{\circ} \mathrm{C}$ in the vacuum oven for 2 days and was subsequently frozen in dry ice. The crude solid was then collected and recrystallized from absolute ethanol to yield $21.3 \mathrm{~g}(74 \%)$ of 3 , with a characteristic melting point of $98^{\circ}$ $99^{\circ} \mathrm{C}$ and the following spectral properties: $\mathrm{IR}(\mathrm{KBr}): 3231,1610(\mathrm{~N}-\mathrm{H})$, $1663(\mathrm{C}=\mathrm{O}), 1251,1027$ (C-O-C), $752 \mathrm{~cm}^{-1}{ }^{1} \mathrm{H}$ NMR $\left(60 \mathrm{MHz}, \mathrm{CDCl}_{3}\right)$ : $3.67\left(\mathrm{~s}, 3 \mathrm{H},-\mathrm{OCH}_{3}\right), 3.77\left(\mathrm{~s}, 2 \mathrm{H}, \mathrm{S}-\mathrm{CH}_{2}\right), 3.98\left(\mathrm{~s}, 2 \mathrm{H}, \mathrm{CO}-\mathrm{CH}_{2}\right), 6.6(\mathrm{~d}$, $\left.J=10,2 \mathrm{H}, \mathrm{H}^{3}, \mathrm{H}^{5^{\prime}}\right), 6.8\left(\mathrm{~d}, J=10,2 \mathrm{H}, \mathrm{H}^{2}, \mathrm{H}^{6}\right), 6.9-7.4(\mathrm{~m}, 3 \mathrm{H}), 8.1(\mathrm{~d}, J=8$, $\left.1 \mathrm{H}, \mathrm{H}^{6}\right) \cdot \mathrm{C}_{16} \mathrm{H}_{16} \mathrm{ClNO}_{2} \mathrm{~S}$. Calculated: C; 59.71, H; 5.01, N; 4.35, Found : C; $59.93, \mathrm{H} ; 4.92, \mathrm{~N} ; 4.31$

\section{$\mathrm{N}$-[2-(4-Methoxybenzylthio)phenyl]-2-homoveratrylaminoa cetamidehydrochloride hemihydrate (4)}

The chloroacetamide $3(1.3 \mathrm{~g}, 0.004 \mathrm{~mol})$ was suspended in 10 $\mathrm{mL}$ benzene under nitrogen atmosphere prior to the addition of diisopropylethylamine $(0.54 \mathrm{~g}, 0.004 \mathrm{~mol})$ to the mixture. Following a 30 -minute stirring period, homoveratrylamine $(0.73 \mathrm{~g}, 0.004 \mathrm{~mol})$ was added in small portions and the mixture was refluxed for 24 -hours. The precipitate that formed was filtered and the solvent was removed under vacuum. The viscous yellow oily residue was crystallized from mixed solvent systems (alcohol/water or acetone/water). The crude solid was filtered and washed twice with water. The product was further purified by recrystallization from ethanol or ethyl acetate to yield $0.11 \mathrm{~g}(<10 \%)$ of 4 , with a melting point of $145.3^{\circ}-146.5^{\circ} \mathrm{C}$, and the following spectral properties: IR (KBr): 3358, 3323, 3267, 2932, 2914, 2833, $1676(\mathrm{C}=\mathrm{O})$, $1577,1541,1517,1249,1026$ (C-O-C) $\mathrm{cm}^{-1}{ }^{1} \mathrm{H} \mathrm{NMR}\left(300 \mathrm{MHz}, \mathrm{CDCl}_{3}\right)$ $2.8\left(\mathrm{t}, 2 \mathrm{H}, \mathrm{C}-\mathrm{CH}_{2}-\mathrm{Ar}\right), 2.93\left(\mathrm{t}, 2 \mathrm{H}, \mathrm{N}-\mathrm{CH}_{2}-\mathrm{C}\right), 3.33\left(\mathrm{~s}, 2 \mathrm{H}, \mathrm{CO}-\mathrm{CH}_{2}-\mathrm{N}\right)$, $3.75\left(\mathrm{~s}, 3 \mathrm{H},-\mathrm{OCH}_{3}\right), 3.87\left(\mathrm{~s}, 6 \mathrm{H}, 2 \mathrm{x}-\mathrm{OCH}_{3}\right), 3.88\left(\mathrm{~s}, 2 \mathrm{H}, \mathrm{S}-\mathrm{CH}_{2}-\right), 6.7-$ $6.9(\mathrm{~m}, 3 \mathrm{H}), 6.8\left(\mathrm{~d}, J=10,2 \mathrm{H}, \mathrm{H}^{3}, \mathrm{H}^{5}\right), 7.0\left(\mathrm{~d}, J=10,2 \mathrm{H}, \mathrm{H}^{2}, \mathrm{H}^{6}\right), 7.05$ $\left(\mathrm{dt}, J=2,8,1 \mathrm{H}, \mathrm{H}^{4}\right), 7.33\left(\mathrm{dt}, J=2,8,1 \mathrm{H}, \mathrm{H}^{5}\right), 7.4\left(\mathrm{dd}, J=2,8,1 \mathrm{H}, \mathrm{H}^{2}\right)$, 8.45 (dd, $J=2,8,1 \mathrm{H}, \mathrm{H}^{6}$ ), 10.32 (br s, $\left.1 \mathrm{H}, \mathrm{NH}-\mathrm{CO}\right) . \mathrm{C}_{26} \mathrm{H}_{31} \mathrm{ClN}_{2} \mathrm{O}_{4} \mathrm{~S} \cdot 0.5$ $\mathrm{H}_{2} \mathrm{O}$. Calculated: $\mathrm{C} ; 60.98, \mathrm{H} ; 6.30, \mathrm{~N} ; 5.47$, Found: $\mathrm{C} ; 60.63, \mathrm{H} ; 6.15$, $\mathrm{N} ; 5.39$.

\section{N-[2-(4-Methoxybenzylthio)phenyl]-2-(N'-methylhomo- veratrylamino)acetamide hydrochloride (5)}

A mixture of chloroacetamide $3(1.3 \mathrm{~g}, 0.004 \mathrm{~mol})$ with $\mathrm{N}$-methylhomoveratrylamine $(0.8 \mathrm{~g}, 0.004 \mathrm{~mol})$ was refluxed for 2224 hours, and was worked up according to the procedure described for compound 4 . The yellow oily residue was triturated with $6 \mathrm{M} \mathrm{HCl}$ solution and a white solid separated. The solid was recrystallized from ethanol (95-100\%) to afford $1.03 \mathrm{~g} \mathrm{(54 \% )}$ of 5, with a melting point of $176^{\circ}-177 \mathrm{C}$ and the following spectral properties: IR $(\mathrm{KBr}): 3119,2991$, 2836, 1676 (C=O), 1600 (N-H), 1248, 1029 (C-O-C), $760 \mathrm{~cm}^{-1}{ }^{1} \mathrm{H}$ NMR $\left(300 \mathrm{MHz}, \mathrm{CDCl}_{3}\right) 3.05\left(\mathrm{~d}, 3 \mathrm{H}, \mathrm{N}^{+}-\mathrm{CH}_{3}\right), 3.15\left(\mathrm{t}, 2 \mathrm{H}, \mathrm{C}-\mathrm{CH}_{2}-\mathrm{Ar}\right), 3.5$ (q, $\left.1 \mathrm{H}, \mathrm{N}^{+}-\mathrm{CH}_{2}-\mathrm{C}\right), 3.65\left(\mathrm{q}, 1 \mathrm{H}, \mathrm{N}^{+}-\mathrm{CH}_{2}-\mathrm{C}\right), 3.70\left(\mathrm{~s}, 3 \mathrm{H},-\mathrm{OCH}_{3}\right), 3.80$, $3.81\left(2 \mathrm{~s}, 6 \mathrm{H}, 2 \mathrm{x}-\mathrm{OCH}_{3}\right), 3.90\left(\mathrm{~s}, 2 \mathrm{H}, \mathrm{CO}-\mathrm{CH}_{2}\right), 4.18\left(\mathrm{~s}, 2 \mathrm{H}, \mathrm{S}-\mathrm{CH}_{2}-\right)$, 6.7-6.8 (m, 3H), $6.75\left(\mathrm{~d}, J=8,2 \mathrm{H}, \mathrm{H}^{3}, \mathrm{H}^{5}\right), 7.0\left(\mathrm{~d}, J=8,2 \mathrm{H}, \mathrm{H}^{2}, \mathrm{H}^{6}\right)$, $7.1\left(\mathrm{t}, J=8,1 \mathrm{H}, \mathrm{H}^{4}\right), 7.25\left(\mathrm{t}, J=10,1 \mathrm{H}, \mathrm{H}^{5}\right), 7.4\left(\mathrm{~d}, J=8,1 \mathrm{H}, \mathrm{H}^{2}\right), 7.8(\mathrm{~d}$, $\left.J=10,1 \mathrm{H}, \mathrm{H}^{6}\right), 9.5($ br s, $1 \mathrm{H}, \mathrm{NH}-\mathrm{CO}), 11.9\left(\mathrm{q}, 1 \mathrm{H}, \mathrm{NH}^{+}\right) \cdot \mathrm{C}_{27} \mathrm{H}_{33} \mathrm{ClN}_{2} \mathrm{O}_{4} \mathrm{~S}$ Calculated: C; 62.72, H; 6.43, N; 5.42, Found : C; 62.71, H; 6.56, N; 5.33.

\section{2-(4-Methoxyphenylthio)-1-nitrobenzene $(6)[18,19]$}

Using previously reported the literature procedure compound 6 was synthesized as follows: To a solution of sodium carbonate ( $23.4 \mathrm{~g}$ anhydrous powder, $0.22 \mathrm{~mol}$ ) in $100 \mathrm{~mL}$ of water was added 4-methoxythiophenol $(25.2 \mathrm{~g}, 0.18 \mathrm{~mol})$. This produced a cloudy suspension after 5 minutes stirring. A warm solution of 1-chloro-2nitrobenzene $(28.1 \mathrm{~g}, 0.18 \mathrm{~mol})$ in $125 \mathrm{~mL}$ of $95 \%$ ethanol was added, and the reaction mixture was heated at $83^{\circ} \mathrm{C}$ for 6 hours after which a golden-orange mixture and white precipitate were observed. On cooling the reaction, $400 \mathrm{~mL}$ of water was gradually added to quench the reaction and dissolve salts. The insoluble brown solid was filtered, washed with water, slurred in $200 \mathrm{~mL}$ methanol, and dried to give $36.9 \mathrm{~g}$ (79\%-yield) of 6 , melting point $94^{\circ}-96^{\circ} \mathrm{C}$. The compound was previously reported $[19,20]$, with the same melting point range.

\section{2-(4-Methoxyphenylthio) aniline (7)}

Compound 7 was synthesized from compound 6 (36.9 g, $0.14 \mathrm{~mol}$ ) following the protocol to prepare compound 2. Stannous chloride dihydrate $(190 \mathrm{~g}, 0.84 \mathrm{~mol})$ was used and the reaction time was 30 minutes $\left(83^{\circ} \mathrm{C}\right)$ or until obtaining a colorless solution. The ivory solid formed after alkalinization with sodium hydroxide was collected, and subjected to purification as described below. The crude material $(33.0$ g) was extracted from a large Soxhlet apparatus with $400 \mathrm{~mL}$ of t-butyl methyl ether. This extract was collected and concentrated to $100 \mathrm{~mL}$ to which equivalent volume of hexane was added. The ether/hexane mixture was seeded and left overnight at $4^{\circ} \mathrm{C}$, after which it yielded a white precipitate of $7(24.8 \mathrm{~g}, 76 \%)$. The precipitate was collected and washed twice with hexane. Upon exposure to air, the white crystals turned darker. Compound 7 had a melting point of $62^{\circ}-63^{\circ} \mathrm{C}$ and the following spectral properties: IR (KBr): 3458, $3363(\mathrm{~N}-\mathrm{H}), 1604,1491$ $(\mathrm{C}=\mathrm{C}), 1244,1020$ (C-O-C), 824, $762 \mathrm{~cm}^{-1},{ }^{1} \mathrm{H}$ NMR (60 MHz, $\mathrm{CDCl}_{3}$ ): $3.72\left(\mathrm{~s}, 3 \mathrm{H},-\mathrm{OCH}_{3}\right), 4.2\left(\mathrm{br}, 2 \mathrm{H}, \mathrm{NH}_{2}\right), 6.4-7.4(\mathrm{~m}, 4 \mathrm{H}), 6.7(\mathrm{~d}, J=9,2 \mathrm{H}$, $\left.\mathrm{H}^{3^{\prime}}, \mathrm{H}^{5}\right), 7.07\left(\mathrm{~d}, J=9,2 \mathrm{H}, \mathrm{H}^{2}, \mathrm{H}^{6^{\prime}}\right)$.

\section{2'-(4-Methoxyphenylthio)-2-chloroacetanilide (8)}

The candidate compound was synthesized from aniline 7 (11.6 g, $0.05 \mathrm{~mol}$ ) using a protocol similar to that used in compound 3. On addition of chloroacetyl chloride $(6.8 \mathrm{~g}, 0.06 \mathrm{~mol})$, a mild temperature rise to $19^{\circ}-20^{\circ} \mathrm{C}$ was observed. The reaction was performed over 30 minutes at room temperature, and the crude product was re-crystallized from absolute ethanol to yield $8.9 \mathrm{~g}$ ( $58 \%$ yield) of 8 , melting point 75 ${ }^{\circ}-76^{\circ} \mathrm{C}$ with the following spectral properties: IR (KBr): $3328(\mathrm{~N}-\mathrm{H})$, $1687(\mathrm{C}=\mathrm{O}), 1582,1528,1244,1030(\mathrm{C}-\mathrm{O}-\mathrm{C}), 834,762 \mathrm{~cm}^{-11} \mathrm{H}$ NMR $\left(60 \mathrm{MHz}, \mathrm{CDCl}_{3}\right) 3.74\left(\mathrm{~s}, 3 \mathrm{H},-\mathrm{OCH}_{3}\right), 4.1\left(\mathrm{~s}, 2 \mathrm{H}, \mathrm{CO}-\mathrm{CH}_{2}\right), 6.6-7.6(\mathrm{~m}$, $4 \mathrm{H}), 6.77\left(\mathrm{~d}, J=8,2 \mathrm{H}, \mathrm{H}^{3}, \mathrm{H}^{5}\right), 7.17\left(\mathrm{~d}, J=8,2 \mathrm{H}, \mathrm{H}^{2}, \mathrm{H}^{6}\right), 8.3\left(\mathrm{~d}, 1 \mathrm{H}, \mathrm{H}^{6}\right)$. $\mathrm{C}_{15} \mathrm{H}_{14} \mathrm{ClNO}_{2} \mathrm{~S}$ Calculated: C; 58.53, H; 4.58, N; 4.55, Found: C; 58.47, $\mathrm{H} ; 4.61, \mathrm{~N} ; 4.63$.

\section{N-[2-(4-methoxyphenylthio)phenyl]-2-homoveratry laminoacetamide hydrochloride (9)}

To the suspension of chloroacetamide $8(0.62 \mathrm{~g}, 0.002 \mathrm{~mol})$ in $7 \mathrm{~mL}$ 
benzene was added diisopropylethylamine $(0.27 \mathrm{~g}, 0.002 \mathrm{~mol})$. After 5 minutes stirring, homoveratrylamine $(0.36 \mathrm{~g}, 0.002 \mathrm{~mol})$ was added in small portions and the mixture was refluxed for 24 hours. The solid precipitate was filtered and the solvent was removed under vacuum. The yellow oil residue was stirred in $20 \mathrm{~mL}$ of $6 \mathrm{M} \mathrm{HCl}$ for 15 minutes. The crude solid precipitated out was filtered and washed three times with water. This product was further purified by recrystallization from $95 \%$ ethanol to yield $0.3 \mathrm{~g}$ ( $31 \%$ yield) of 9 , melting point $188.4^{\circ}-189.3^{\circ} \mathrm{C}$ with the following spectral properties: IR $(\mathrm{KBr}) 3205(\mathrm{~N}-\mathrm{H}), 3111$, 3005, 2833, $1707(\mathrm{C}=\mathrm{O}), 1591(\mathrm{~N}-\mathrm{H}), 1515,1464(\mathrm{C}=\mathrm{C}), 1256,1037$ (C-O-C), $758 \mathrm{~cm}^{-1}$. ${ }^{1} \mathrm{H}$ NMR (300 MHz,DMSO) 2.93 (t, 2H, C-CH $\mathrm{Ar}), 3.20\left(\mathrm{t}, 2 \mathrm{H}, \mathrm{N}-\mathrm{CH}_{2}-\mathrm{C}\right), 3.73,3.75,3.77\left(3 \mathrm{~s}, 9 \mathrm{H}, 3 \mathrm{x}-\mathrm{OCH}_{3}\right), 4.02(\mathrm{~s}$, $\left.2 \mathrm{H}, \mathrm{CO}-\mathrm{CH}_{2}-\mathrm{N}\right), 6.77-6.93(\mathrm{~m}, 3 \mathrm{H}), 7.0\left(\mathrm{~d}, J=8,1 \mathrm{H}, \mathrm{H}^{3}\right), 7.02(\mathrm{~d}, J=10$, $\left.2 \mathrm{H}, \mathrm{H}^{3}, \mathrm{H}^{5}\right), 7.17\left(\mathrm{t}, J=8,1 \mathrm{H}, \mathrm{H}^{4}\right), 7.25\left(\mathrm{t}, J=8,1 \mathrm{H}, \mathrm{H}^{5}\right), 7.37(\mathrm{~d}, J=10$, $\left.2 \mathrm{H}, \mathrm{H}^{2}, \mathrm{H}^{6}\right), 7.45\left(\mathrm{~d}, J=8,1 \mathrm{H}, \mathrm{H}^{6}\right), 9.38\left(\mathrm{br}, 2 \mathrm{H}, \mathrm{NH}_{2}^{+}\right), 10.38(\mathrm{~s}, 1 \mathrm{H}$, -NH-CO). $\mathrm{C}_{25} \mathrm{H}_{29} \mathrm{ClN}_{2} \mathrm{O}_{4} \mathrm{~S}$ Calculated: C; 61.40, $\mathrm{H} ; 6.00, \mathrm{~N} ; 5.73$, Found : C; 61.37, H; 6.10, N; 5.92.

\section{N-[2-(4-Methoxyphenylthio)phenyl]-2-(N'-methylhomove- ratrylamino)acetamide hydrochloride hemihydrate (10)}

Compound 10 was prepared in $60 \%$ yield from compound $8(1.2$ g, $0.004 \mathrm{~mol}$ ) using the same procedure used to prepare compound 9 . $\mathrm{N}$-methylhomoveratrylamine $(0.86 \mathrm{~g}, 0.04 \mathrm{~mol})$ was substituted for homoveratrylamine and the reflux time was $24-26$ hours. The resulting yellow oil residue was triturated with $6 \mathrm{M} \mathrm{HCl}$ solution to yield a crude solid. This crude product was washed with small amount of water and recrystallized from ethanol to afford $1.2 \mathrm{~g}$ of 10 , with a melting point of $159.5^{\circ}-161^{\circ} \mathrm{C}$ and the following spectral properties: IR (KBr) 3446, 3400-2500 (N-H), $1674(\mathrm{C}=\mathrm{O}), 1580(\mathrm{~N}-\mathrm{H}), 1517,1473(\mathrm{C}=\mathrm{C}), 1027$ (C-O-C), $829(\mathrm{C}-\mathrm{H}) \mathrm{cm}^{-1} .{ }^{1} \mathrm{H}$ NMR $\left(300 \mathrm{MHz}, \mathrm{CDCl}_{3}\right) 2.2(\mathrm{~s}, 1 \mathrm{H},-\mathrm{OH})$, $3.08\left(\mathrm{~d}, 3 \mathrm{H}, \mathrm{N}^{+}-\mathrm{CH}_{3}\right), 3.18\left(\mathrm{~m}, 2 \mathrm{H}, \mathrm{C}-\mathrm{CH}_{2}-\mathrm{Ar}\right), 3.5\left(\mathrm{q}, 1 \mathrm{H}, \mathrm{N}^{+}-\mathrm{CH}_{2}-\mathrm{C}\right)$, $3.7\left(\mathrm{q}, 1 \mathrm{H}, \mathrm{N}^{+}-\mathrm{CH}_{2}-\mathrm{C}\right), 3.75\left(\mathrm{~s}, 3 \mathrm{H},-\mathrm{OCH}_{3}\right), 3.80,3.82(2 \mathrm{~s}, 6 \mathrm{H}, 2 \mathrm{x}$ $\left.-\mathrm{OCH}_{3}\right), 4.4\left(\mathrm{~s}, 2 \mathrm{H}, \mathrm{CO}-\mathrm{CH}_{2}-\mathrm{N}\right), 6.7-7.3(\mathrm{~m}, 10 \mathrm{H}), 7.55(\mathrm{~d}, J=9,1 \mathrm{H}$, $\left.\mathrm{H}^{6}\right), 10.13(\mathrm{~s}, 1 \mathrm{H},-\mathrm{NH}-\mathrm{CO}), 11.82\left(\mathrm{q}, 1 \mathrm{H}, \mathrm{NH}^{+}\right) \cdot \mathrm{C}_{26} \mathrm{H}_{31} \mathrm{ClN}_{2} \mathrm{O}_{4} \mathrm{~S} \cdot 0.5$ $\mathrm{H}_{2} \mathrm{O}$ Calculated: $\mathrm{C} ; 60.98, \mathrm{H} ; 6.30, \mathrm{~N} ; 5.47$, Found : C; 61.17, H; 6.34, N; 5.62 .

\section{In vitro assay}

After the approval of the Institutional Animal Care and Use Committee (IACUC) of the MCPHS University, Male Wistar rats (Charles River Laboratory, Wilmington MA) were housed in 12" X 24 " plastic cages in the animal facility with a 12 hours light and 12 hours dark schedule. Animals had ad libitum access to water and food. Rats (weighing approximately $350 \mathrm{~g}$ ) were euthanized with sodium pentobarbital $(100 \mathrm{mg} / \mathrm{kg})$. The thoracic aorta was removed and placed in a $37^{\circ} \mathrm{C}$ Krebs-bicarbonate solution containing $\mathrm{NaCl}, 112 \mathrm{mM} ; \mathrm{KCl}$, $5 \mathrm{mM} ; \mathrm{MgSO}_{4}, 1.2 \mathrm{mM} ; \mathrm{KH}_{2} \mathrm{PO}_{4}, 1 \mathrm{mM} ; \mathrm{NaHCO}_{3}, 25 \mathrm{mM} ; \mathrm{CaCl}_{2}$, $1.25 \mathrm{mM}$ and glucose, $11.5 \mathrm{mM}$ (pH 7.4). The solution was prepared fresh on each day of an experiment and aerated with $95 \% \mathrm{O}_{2}$ and $5 \%$ $\mathrm{CO}_{2}$. After removal of connective tissues, the aortic strip was cut into rings that were approximately $2.5-3.0 \mathrm{~mm}$ in length and immersed in a $37^{\circ} \mathrm{C}$ Krebs-bicarbonate solution. An Iso-temp Constant Temperature Circulator (Fisher Scientific model 801, Pittsburgh, PA) was used to maintain the bath temperature. Tissues were suspended between two stainless steel loops. To measure tissue contraction and relaxation one of the loops was attached to a fixed glass tube that provided the gas mixture to the solution and the other loop was attached to a Grass forcedisplacement transducer via polyester thread to a Grass Polygraph (model 7H, Grass Instruments, Quincy, MA). Each preparation was stretched to an optimal resting tension of $2.0 \mathrm{~g}$ (previously determined by measuring tissue contraction to $\mathrm{Ca}^{2+}$ concentrations of $0.1-8.0$ $\mathrm{mM}$ ) that was maintained in all experiments. All test compounds were dissolved in absolute ethanol that was also used to prepare all other concentrations (0.01-10.0 mM) of the test compounds. A $150 \mathrm{mM}$ calcium chloride stock solution was prepared in de-ionized water. A group of 4-5 animals was used to evaluate each compound. Following equilibration for 60 -minutes with the above solution, tissues were washed every 15 minutes with fresh Krebs-bicarbonate solution.

After the artery preparations were equilibrated in the normal Krebs-bicarbonate solution, the solution was replaced with a calciumfree, potassium-rich Krebs-bicarbonate solution $(\mathrm{NaCl}, 17 \mathrm{mM}$; $\mathrm{KCl}, 100 \mathrm{mM} ; \mathrm{MgSO}_{4}, 1.2 \mathrm{mM} ; \mathrm{KH}_{2} \mathrm{PO}_{4}, 1 \mathrm{mM}$; $\mathrm{NaHCO}_{3}, 25 \mathrm{mM}$ and glucose, $11.5 \mathrm{mM}$ ( $\mathrm{pH}$ 7.4) to induce depolarization. Tissues were washed every 15-minutes with the calcium-free, potassium-rich Krebs-bicarbonate solution. Following equilibrium, $0.1 \mathrm{~mL}$ of absolute ethanol (vehicle control) was added to the tissue. After 10-minutes incubation with ethanol, the contractile baseline response was obtained by adding $0.1 \mathrm{~mL}$ of a calcium chloride stock solution (to give 1.5 $\mathrm{mM} \mathrm{Ca}{ }^{2+}$ final concentration in the tissue bath). After obtaining the maximum responses with $1.5 \mathrm{mM}$ of $\mathrm{Ca}^{2+}$ the tissues were washed every 15 minutes with calcium-free, potassium-rich Krebs-bicarbonate solution for 1-hour. Once the tension had remained stable for at least 15 minutes, a second (control) response was obtained in the same manner. After monitoring the second response, the tissues were washed again every 15 minutes with calcium-free potassium-rich Krebs bicarbonate solution for one hour. Once tension had remained stable for at least 15 minutes tissues were treated (incubation period of 10 minutes) with 0.1 $\mathrm{mL}$ of the corresponding test compound solution in absolute ethanol to give the required final concentrations of $0.1-100 \mu \mathrm{M}$. The contractile response at each concentration was measured after adding $0.1 \mathrm{~mL}$ of $\mathrm{CaCl}_{2}$ stock solution (150 mM, $1.5 \mathrm{mM}$ in the tissue bath). Responses to all test compounds (at final concentrations of $0.1-100 \mu \mathrm{M}$ in tissue bath) were obtained. Each tissue received only one concentration of each test compound. The results of these experiments were expressed as percent contraction inhibition compared to the initial contraction. The percentage of contraction inhibition was calculated for each tissue as follows: \% Inhibition $=100-($ contraction TC/contraction CC X 100), where contraction TC denotes the maximum response in the presence of the test compound and contraction CC denotes the maximum response under control condition. Dose-response curves were constructed and $\mathrm{IC}_{50}$ values were calculated.

\section{Results and Discussion}

Table 1 data reveal that all four compounds, 4,5,9 \&10, are with moderate calcium channel blocking activities. Table 1 also reveals that the new hybrid compounds are generally less active than either diltiazem or verapamil, but with $\mathrm{IC}_{50}$ value ranges within the same order of magnitude obtained for the two parent drugs. After 10-minute incubation, the hybrid compounds exhibited an $\mathrm{IC}_{50}$ value range of 3.7 - $12.0 \mu \mathrm{M}$. However, after 2-hour incubation, the $\mathrm{IC}_{50}$ range was 0.78 $2.12 \mu \mathrm{M}$, reflecting approximately a five-fold increase in activity. The observed activities after the 10-minute incubation may indicate that the compounds have activities at the exterior sites of the membrane. The almost five-fold increase in activities of the same set of compounds after 2-hour incubation suggests that the compounds may have higher affinity to the sites located close to the interior side of the membrane. The hybrid compounds were generally found to be less active than diltiazem and verapamil that were tested under the same assay conditions and incubation times. As depicted in Table 1, diltiazem exhibited $\mathrm{IC}_{50}$ values of $0.26 \& 0.14 \mu \mathrm{M}$ after 10-minute and 2-hour incubations, respectively, while verapamil exhibited $\mathrm{IC}_{50}$ values of $0.47 \& 0.14 \mu \mathrm{M}$, after 10 -minute and 2-hour incubations, respectively. Increasing the incubation time from 10-minute to 2-hourst resulted in case of diltiazem in less than a 2-fold decrease in the $\mathrm{IC}_{50}$. In contrast, the increase of the incubation 
time from 10 -minute to 2 -hour in case of verapamil resulted in an almost 5 -fold decrease in the $\mathrm{IC}_{50}$ value. These results confirm earlier reports that diltiazem binding domains are mainly located close to outer side of the membrane, and that of verapamil more to the interior side [10-15].

Table 1 depicts that the hybrid compounds possess dual binding to the membrane domains of both diltiazem and verapamil. However, the data also suggest that the hybrid molecules have a profile closer to verapamil than that of diltiazem. Earlier reports suggested that compounds with a thiazepine-like backbone, diltiazem class, or an aryl-alkyl amine backbone, verapamil class, exhibited affinity to both the interior and exterior sites of the membrane [21,22]. On another note of structure activity relationships, Table 1 depicts that the replacement of the 4-methoxybenzylthio group of compounds $4 \& 5$ with a 4-methoxyphenylthio group in compounds $9 \& 10$, resulted in no significant difference in activity. A similar conclusion could be drawn for the tertiary amines (compounds $5 \& 10$ ), versus the secondary amines (compounds $4 \& 9$ ). Finally, in spite of the fact that most of the current hybrid compounds showed weaker activity relative to the two reference drugs; the 2-hour-incubation data (Table 1), indicate that compound 5 , with an $\mathrm{IC}_{50}$ of $0.78 \mu \mathrm{M}$ to be a promising compound for further structural activity studies and to confirm that the mechanism of action is unequivocally through blocking calcium channels using other electrophysiology techniques such as patch clamp, voltage clamp, confocal laser scanning microscopy, and direct binding studies.

\section{Conclusions}

In summary, four o-thioacetanilide compounds; designed as hybrid molecules of diltiazem and verapamil, were synthesized and evaluated for calcium channel blocking activities. The hybrid compounds were found to be active in inhibiting aortic strip contractions but with less activity than either of the two parent drugs. The design of hybrid molecules may still generate active compounds, but not necessarily with higher activity than the starting individual parent drugs.

\section{Acknowledgments}

The authors would like to thank MCPHS University in Boston MA for funding this research. Special thanks to Dr. Charles Kelly, associate Professor of Organic Chemistry at MCPHS University for providing some starting materials used in the syntheses.

\section{References}

1. Herman ZS (1999) Application of calcium channel blockers in the treatment of cardiovascular diseases. Pol J Pharmacol 51: 201-206.

2. Araie M, Mayama C (2011) Use of calcium channel blockers for glaucoma. Prog Retin Eye Res 30: 54-71.

3. Casamassima F, Hay AC, Benedetti A, Lattanzi L, Cassano GB, et al. (2010) L-type calcium channels and psychiatric disorders: A brief review. Am J Med Genet B Neuropsychiatr Genet 153B: 1373-1390.

4. Pfeiffer RF (2010) Parkinson disease: calcium channel blockers and Parkinson disease. Nat Rev Neurol 6: 188-189.

5. Ritz B, Rhodes SL, Qian L, Schernhammer E, Olsen JH, et al. (2010) L-type calcium channel blockers and Parkinson disease in Denmark. Ann Neurol 67: 600-606.

6. Shah N, Kumar A, Vazhudhi N K, Winston A, Blessed E, et al. (2012) An animal study on the effect of different classes of organic calcium channel blockers in wound healing. Biomed Res 2: 521-525.
7. Patil PA, Agnihotri RL, Singh KR (2009) Influence of calcium channel blockers on wound healing - an experimental study. Pharmacology online 2: 1125-1135.

8. Otoom S, Hasan Z (2006) Nifedipine inhibits picrotoxin-induced seizure activity: further evidence on the involvement of L-type calcium channel blockers in epilepsy. Fundam Clin Pharmacol 20: 115-119.

9. Chen J, Cha-Molstad H, Szabo A, Shalev A (2009) Diabetes induces and calcium channel blockers prevent cardiac expression of proapoptotic thioredoxininteracting protein. Am J Physiol Endocrinol Metab 296: E1133-1139.

10. Tsukuda K, Mogi M, Li JM, Iwanami J, Min LJ, et al. (2008) Diabetes-associated cognitive impairment is improved by a calcium channel blocker, nifedipine. Hypertension 51: 528-533.

11. Nakayama $H$, Kuniyasu A (1996) Identification of binding sites for calcium channel antagonists. Jpn Heart J 37: 643-650.

12. Striessnig J, Glossmann H, Catterall WA (1990) Identification of a phenylalkylamine binding region within the alpha 1 subunit of skeletal muscle Ca2+ channels. Proc Natl Acad Sci U S A 87: 9108-9112.

13. Striessnig J, Grabner M, Mitterdorfer J, Hering S, Sinnegger MJ, et al. (1998) Structural basis of drug binding to $\mathrm{L} \mathrm{Ca2+}$ channels. Trends Pharmacol Sci 19 108-115.

14. Kurokawa J, Adachi-Akahane S, Nagao T (1997) ,5-benzothiazepine binding domain is located on the extracellular side of the cardiac L-type Ca2+ channel. Mol Pharmacol 51: 262-268.

15. Hering S, Savchenko A, Strubing C, Lakitsch M, Striessnig J (1993) Extracellular localization of the benzothiazepine binding domain of L-type Ca2+ channels. Mol Pharmacol 43: 820-826.

16. Marriott JF (1988) A comparison of the effects of the calcium entry blockers, verapamil, diltiazem and flunarizine against contractions of the rat isolated aorta and portal vein. Br J Pharmacol 95: 145-154.

17. Mehanna AS, Kim JY (2005) Design, synthesis, and biological testing of thiosalicylamides as a novel class of calcium channel blockers. Bioorg Med Chem 13: 4323-4331.

18. Kauffman JM, Litak PT (1995) Photophysical Properties of Fluorescent Dibenzofurans, a Dibenzothiophene, and Carbazoles Substituted with Benzoxazole and Hydroxyl Groups to Produce Excited Statelntramolecular Proton-transfer. J Heterocyc Chem 32: 1541-1555.

19. Kauffman JM, Litak PT (1996) Benzazole Compounds with ESIPT Fluorescence. US Patent 5:112.

20. Kanaide H, Kobayashi S, Nishimura J, Hasegawa M, Shogakiuchi Y, et al (1988) Quin2 microfluorometry and effects of verapamil and diltiazem on calcium release from rat aorta smooth muscle cells in primary culture. Circ Res 63: $16-26$

21. Kimball SD, Hunt JT, Barrish JC, Das J, Floyd DM, et al. (1993) 1-Benzazepin2-one calcium channel blockers--VI. Receptor-binding model and possible relationship to desmethoxyverapamil. Bioorg Med Chem 1: 285-307.

22. Berjukov S, Aczel S, Beyer B, Kimball SD, Dichtl M, et al. (1996) Extra- and intracellular action of quaternary devapamil on muscle L-type $\mathrm{Ca}(2+)$-channels. Br J Pharmacol 119: 1197-1202. 